\title{
Perspectives on Rangeland Management Education and Research in Argentina
}

\section{By David L. Anderson, Griselda L. Bonvissuto, Miguel A. Brizuela, Guillermo Chiossone, Andrés F. Cibils, M. Silvia Cid, Israel Feldman, Roberto C. Fernández Grecco, Carlos Kunst, Martín Oesterheld, Gabriel E. Oliva, José M. Paruelo, H. Raúl Peinetti, and E. Sebastián Villagra}

\section{Argentina's Rangelands}

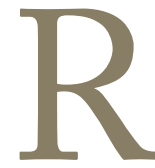
angelands account for over two-thirds of Argentina's land area and contribute uniquely to its biodiversity, agricultural livelihood, and cultural identity. Colossal mountain ranges and regional air mass movements create a variety of climates that generate an equally diverse array of rangeland and forest biomes (Table 1; Fig. 1). Humid tropical air currents that flow into the continent from the Atlantic Ocean create a NESW gradient of decreasing precipitation across the northern half of Argentina's territory. Along this gradient, subtropical forests are gradually replaced by subhumid woodlands and extensive subtropical and temperate grasslands that eventually give way to semiarid savannas and desert scrublands (Fig. 1). The southern half of Argentina's land area (also known as Patagonia) exhibits climate and vegetation patterns that are controlled almost entirely by the orographic effects of the Cordillera de los Andes. This mountain range, which runs in a $\mathrm{N}-\mathrm{S}$ direction along Argentina's western border, stands in the way of mid-latitude westerlies and thus creates a region-wide rain shadow that hosts some of the continent's most extensive cold deserts and semi-deserts.

Argentina's rangelands are not exempt from land use pressures that occur in similar environments across the globe. Challenges ranging from tilling of rangelands to replace natural vegetation with crops to woody plant encroachment and desertification of arid grazing lands have been the focus of several decades of research, education, and outreach. Argentina's rangelands will set the stage for the upcoming IX International Rangeland Congress (IRC) in April 2011, and in this paper we seek to 1) provide insights into the current state of rangeland management education and research in Argentina, 2) spark curiosity about Argentina's rangelands, and 3) elicit interest in the Rosario 2011 IRC, which will be the first of its kind to be hosted by a South American country (www.irc2011.com.ar).

\section{History of Range Science in Argentina}

The applied practice of range science in Argentina is now more than 60 years old. Some of the earliest rangelandrelated research was published at the beginning of the twentieth century and dealt with livestock husbandry on rangelands of Patagonia, ${ }^{1}$ geobotany, ${ }^{2}$ the description of grasslands detailing native and introduced grasses in Argentina and their importance and effect on livestock production, ${ }^{3}$ as well as detailed accounts of the relationships between sheep grazing and vegetation in northern Patagonia. ${ }^{4}$ Beginning in 1948, Alberto Soriano, Professor of Agronomy at the Universidad de Buenos Aires, initiated a long series of well-documented descriptions of the vegetation and the impact of grazing on vegetation and soils in Patagonia including Tierra del Fuego. He detailed native vegetation composition and its response to grazing and lack of appropriate management and suggested measures to mitigate negative impacts. ${ }^{5}$

Alberto Soriano may not have been the first, but he became the most influential range researcher because he related the full ecosystem concept to livestock practices. In a sense, the laboratory and field studies initiated by Soriano along with many of his co-workers and students continue today and have extended our knowledge, not only of Patagonia, but also of the humid and subhumid Pampas including the Flooding Pampas of the Province of Buenos Aires. Students trained in Soriano's philosophy and work 
Table 1. Rangeland types of Argentina

\begin{tabular}{|c|c|c|c|c|c|}
\hline & Rangeland type & Area (ha) & $\begin{array}{l}\text { Mean rainfall } \\
(\mathrm{mm} / \text { year })\end{array}$ & $\begin{array}{l}\text { Plant communities } \\
\text { (physiognomy) }\end{array}$ & Dominant plant species \\
\hline \multirow{7}{*}{$\begin{array}{l}\text { Arid and } \\
\text { semiarid } \\
\text { grasslands, } \\
\text { shrublands, } \\
\text { and wood- } \\
\text { lands* }\end{array}$} & \multirow{3}{*}{$\begin{array}{l}\text { Patagonia (cold } \\
\text { deserts and } \\
\text { semi-deserts) }\end{array}$} & \multirow[b]{3}{*}{60 million } & \multirow[b]{3}{*}{300} & Shrub steppes & $\begin{array}{l}\text { Mulinum spinosum, Adesmia campestris, } \\
\text { Junellia tridens, Stipa humilis, Stipa } \\
\text { speciosa, Poa ligularis }\end{array}$ \\
\hline & & & & Grass steppes & $\begin{array}{l}\text { Festuca pallescens, Festuca gracillima, } \\
\text { Poa dusenii, Beberis heterophylla }\end{array}$ \\
\hline & & & & $\begin{array}{l}\text { Meadows (valley } \\
\text { bottoms) }\end{array}$ & $\begin{array}{l}\text { Festuca pallescens, Juncus balticus, } \\
\text { Holcus lanatus, Poa pratensis }\end{array}$ \\
\hline & $\begin{array}{l}\text { Monte (hot and } \\
\text { cold deserts and } \\
\text { semi-deserts) }\end{array}$ & 46 million & $80-300$ & Shrub steppes & $\begin{array}{l}\text { Larrea divaricata, Prosopis alpataco, } \\
\text { Lycium chilense, Trichloris crinita, Eragrostis } \\
\text { argentina, Bouteloua aristidoides }\end{array}$ \\
\hline & $\begin{array}{l}\text { Caldenal } \\
\text { (semiarid } \\
\text { woodlands) }\end{array}$ & 2.3 milliont & $350-500$ & Woodlands & $\begin{array}{l}\text { Prosopis caldenia, Condalia microphylla, } \\
\text { Prosopis alpataco, Prosopis flexuosa, } \\
\text { Stipa tenuis, Stipa gynerioides }\end{array}$ \\
\hline & $\begin{array}{l}\text { Western (dry) } \\
\text { Chaco (semiarid } \\
\text { woodlands and } \\
\text { savannas) }\end{array}$ & 65 million & $320-800$ & $\begin{array}{l}\text { Mid- to low forests } \\
\text { and savannas }\end{array}$ & $\begin{array}{l}\text { Schinopsis lorentii, Aspidosperma } \\
\text { quebracho-blanco, Prosopis alba, } \\
\text { Prosopis nigra, Leptochloa virgata, } \\
\text { Paspalum inaequivalva }\end{array}$ \\
\hline & $\begin{array}{l}\text { Puna (cold } \\
\text { deserts and } \\
\text { semi-deserts) }\end{array}$ & 9 million & 200 & Shrub steppes & $\begin{array}{l}\text { Junellia sp., Chuquiraga sp., Nardophyllum } \\
\text { sp., Adesmia sp., Mulinum sp., Stipa } \\
\text { caespitose, Stipa leptosthchya }\end{array}$ \\
\hline \multirow[t]{2}{*}{$\begin{array}{l}\text { Subtropical } \\
\text { humid for- } \\
\text { ests and } \\
\text { savannas* }\end{array}$} & $\begin{array}{l}\text { Eastern (wet) } \\
\text { Chaco (subhumid } \\
\text { forests and } \\
\text { savannas) } \neq\end{array}$ & 25 million & 800 & $\begin{array}{l}\text { Forests and } \\
\text { savannas }\end{array}$ & $\begin{array}{l}\text { Schinopsis lorentzii, Aspidosperma quebra- } \\
\text { cho blanco, Schinopsis balansae, Prosopis } \\
\text { alba, Prosopis nigra, Elionurus muticus, } \\
\text { Sorghastrum agrostoides, Panicum prionites, } \\
\text { Paspalum intermedium, Paspalum almum, } \\
\text { Paspalum urvillei, Spartina argentinensis, } \\
\text { Juncus capillaceus, Juncus macrocephallus }\end{array}$ \\
\hline & $\begin{array}{l}\text { Espinal (forests, } \\
\text { woodlands, } \\
\text { savannas) }\end{array}$ & 3 million & $1,000-1,200$ & $\begin{array}{l}\text { Forests and } \\
\text { savannas }\end{array}$ & $\begin{array}{l}\text { Prosopis alba and Prosopis nigra, Prosopis } \\
\text { algarrobilla, Butia yatay, Setaria geniculata, } \\
\text { Bothriochloa laguroides, Paspalum urbillei, } \\
\text { Paspalum dilatatum }\end{array}$ \\
\hline $\begin{array}{l}\text { Temperate } \\
\text { humid } \\
\text { grasslands* }\end{array}$ & $\begin{array}{l}\text { Pampas (temper- } \\
\text { ate grasslands } \\
\text { and grass } \\
\text { steppes) }\end{array}$ & 50 million & $700-900$ & Grasslands & $\begin{array}{l}\text { Paspalum dilatatum, Lolium multiflorum, Stipa } \\
\text { neesiana (uplands); Bothriochloa laguroides, } \\
\text { Stipa papposa (plains); Leersia hexandra, } \\
\text { Glyceria multiflora (humid lowlands); Distichlis } \\
\text { spicata (alkaline lowlands); Paspalum quadri- } \\
\text { farium (uplands, plains, and humid lowlands) }\end{array}$ \\
\hline $\begin{array}{l}\text { Sub- } \\
\text { Antarctic } \\
\text { forests* }\end{array}$ & $\begin{array}{l}\text { Nothofagus for- } \\
\text { ests (temperate } \\
\text { semideciduous } \\
\quad \text { forests) }\end{array}$ & 2 million & $\geq 1,000$ & $\begin{array}{l}\text { Forests and } \\
\text { savannas }\end{array}$ & $\begin{array}{l}\text { Nothofagus pumilio, Nothofagus antartica, } \\
\text { Berberis spp., Holcus lanatus }\end{array}$ \\
\hline \multicolumn{6}{|c|}{$\begin{array}{l}\text { * See Further Readings online at http://dx.doi.org/10.2111/RANGELANDS-D-10-00016.s1 for supporting references. } \\
\text { tOriginally, } 7.5 \text { million. } \\
\text { †Includes subtropical grasslands and wetlands. }\end{array}$} \\
\hline
\end{tabular}

ethic continue to labor in the field and publish in prestigious scientific journals on basic range research and principles of best management practices for a wide range of ecosystems.

Two important milestones shaped the beginning of federally funded, nationwide applied rangeland management research and outreach programs in Argentina. The first occurred in 1953, with an International Course on Pastures co-organized by the Instituto Interamericano de Cooperación para la Agricultura (IICA), the United Nations (FAO), and the Argentine government. Peter Sears, a sheep expert from New Zealand, and Joe Woolfolk, a charter member of the Society for Range Management from Montana, offered this 


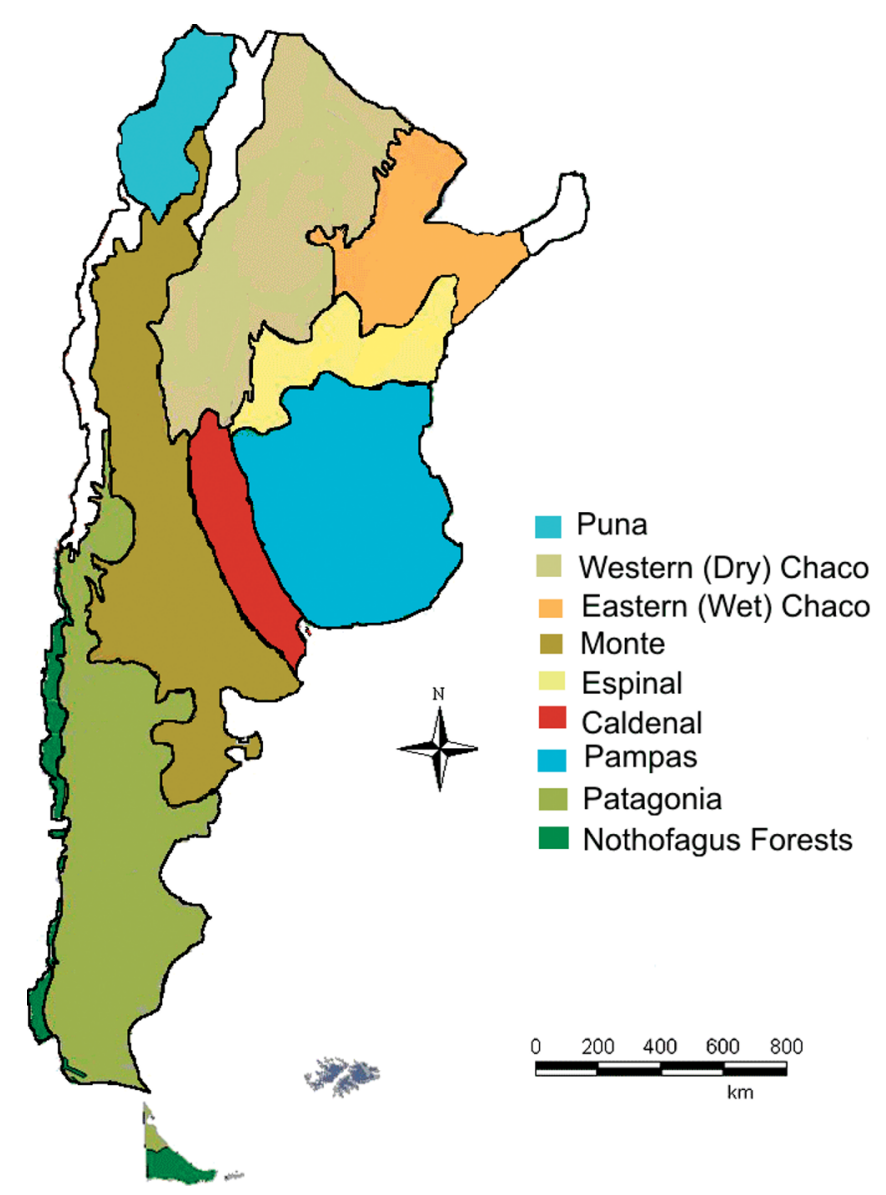

Figure 1. Rangeland types of Argentina. (P. Lagorio, INTA Bariloche)

course at three locations (Esquel, Chubut; General Acha, La Pampa; and Tandil, Buenos Aires) and addressed range management as a discipline discussing sheep and cattle husbandry and grazing practices through visits to different ranches (estancias) and experiment stations. About 20 professionals from Argentina, Chile, Brazil, and Uruguay were trained through this program and later joined many of the incipient rangeland research and extension teams across the country.

The second milestone can be traced back to the establishment of the first rangeland research program at the Instituto Nacional de Tecnología Agropecuaria (INTA, Argentina's agricultural research and extension service) in 1965 under the direction of David Lee Anderson, who together with Guillermo Covas and Eduardo Cano are considered the founders of INTA's rangeland programs. Research activities began on a few acres of native pasture in the semiarid woodlands of San Luis and consisted initially of collecting and keying of native plant species. This was followed by the establishment of a local herbarium and documentation of plant phenology for all the major range species, which involved recording observations on key plant species every 15 days for 20 years. Cattle diet preference trials were then conducted, and a list of animal preference for the plant species composing range pastures in open calden (Prosopis) woodland/grassland was developed. Gradually, as ranchers found out about INTA's interest in researching and managing rangelands, they generously offered their ranches and facilities to test hypotheses and new techniques for improving livestock production through innovative range management grazing systems. Permanent vegetation-monitoring transects were installed at many of these ranches, vegetation-type maps were developed, and available forage-mass to be used in determining potential stocking rates for the grazing systems were estimated.

Much of this early work applied principles and ideas proposed by Stoddart and Smith, Whittaker, Weaver and Clements, Cook, Dyksterhuis, and Daubenmire (see Further Readings online at http://dx.doi.org/10.2111/RANGELANDSD-10-00016.s1 for the citations of these seminal pieces). Since those early days, a large number of researchers, many of whom pursued graduate degrees in rangeland-related disciplines abroad, have contributed to the growth of Range Science in Argentina through their work at national universities, federal research laboratories (Consejo Nacional de Investigaciones Científicas y Técnicas [CONICET]), and INTA. A number of Argentina's rangeland researchers today are considered to be in the forefront of the art and science of rangeland ecology and management.

\section{Current Undergraduate Rangeland-Related Education Programs in Argentina}

Argentina's universities have a longstanding tradition of excellence in training college students for agricultural professions; however, the creation of undergraduate-level programs focusing specifically on natural resource management is fairly new. Most natural resource professionals in Argentina today, particularly those involved with managing Argentina's rangelands, were trained in five- to six-year Agronomy (and to a lesser degree Biology) undergraduate-level programs.

Argentina's first two Agronomy programs were established at the beginning of the twentieth century at public universities (Universidad de Buenos Aires in 1909, www. uba.ar; and Universidad Nacional de La Plata in 1905, www. unlp.edu.ar), and since then the number of programs nationwide has grown to 30, the majority of which (24) continue to be offered at public universities. Five public universities currently offer four- to five-year renewable natural resources (RNR) management programs with slightly different regional emphases depending on the geographic location of each institution. Four of these programs were created within the last 10 years, and although $60 \%$ of the Agronomy degrees are granted by universities located in the Pampas region, all RNR programs, except one, are located in remote arid and semiarid areas of Argentina.

\footnotetext{
The public university system in Argentina offers government-funded free college education to all citizens.
} 
A minimum of 3,000-4,000 class hours are required to obtain a RNR degree in any of the five universities that offer this major. The course load of RNR programs in Argentina appears to be comparable to that of Bachelor of Science degrees in the United States, which require four years of course work and approximately 120 credits (or 3,600 class hours). Even so, RNR curricula in Argentina tend to be of a generalist nature and offer less diversity in areas of specialization compared to the U.S. university system. Argentina's RNR undergraduate programs do not offer students the possibility to choose from potential areas of emphasis such as Rangeland Resources Management, Ranch Management, Watershed Management, Wildlife Habitat Management, Natural Resources Economics and Planning, Rangeland Restoration, and Natural Resources Conservation, all of which are offered, for example, to students at New Mexico State University (www.nmsu.edu).

A great deal of variation exists in faculty training and employment status (full versus part time) among Agronomy programs in Argentina recently accredited by the National Higher Education Assessment and Accreditation Commission (CONEAU). Programs with the ability to develop improved curricula are those offered by institutions with a higher percentage of full-time faculty (54\% with 40 hours or more per week) and with over $50 \%$ of graduate-level education among faculty, including Specializations, Master of Science, and Doctoral degrees obtained at either domestic or foreign universities. ${ }^{6,7}$ Faculty resources and infrastructure of RNR programs have not undergone a detailed analysis to date. Three of these programs are more than 10 years old, and the other two are only five years old, suggesting that their faculty bodies are possibly in consolidation or still in the process of being trained.

According to a recent nationwide accreditation process conducted by CONEAU that assessed standards of quality of the undergraduate Agronomy programs, ${ }^{\text {ii }}$ the amount of time allocated to research activities by faculty in each program also varies across institutions. Between 1999 and 2003 there were on average 65 faculty-driven active research projects per program; however, distribution among institutions was fairly uneven, ranging from zero to 186 per program. Research is funded either by the universities themselves (72.6\%), federal or provincial research funding agencies $(15.4 \%)$, or companies or private institutions (11.9\%). Overall, university in-house research budgets are insufficient to fund complex projects. Research results are mostly presented at scientific and professional conferences (63.5\%) but are also published in peer-reviewed journals, indexed or not (29.8\%), published as books or book chapters (5.9\%), or patented as intellectual property $(0.8 \%)$. Approximately 98\% of the scientific production associated with Agronomy programs is generated by faculty at public universities.

ii M. A. Brizuela served on this accreditation committee.
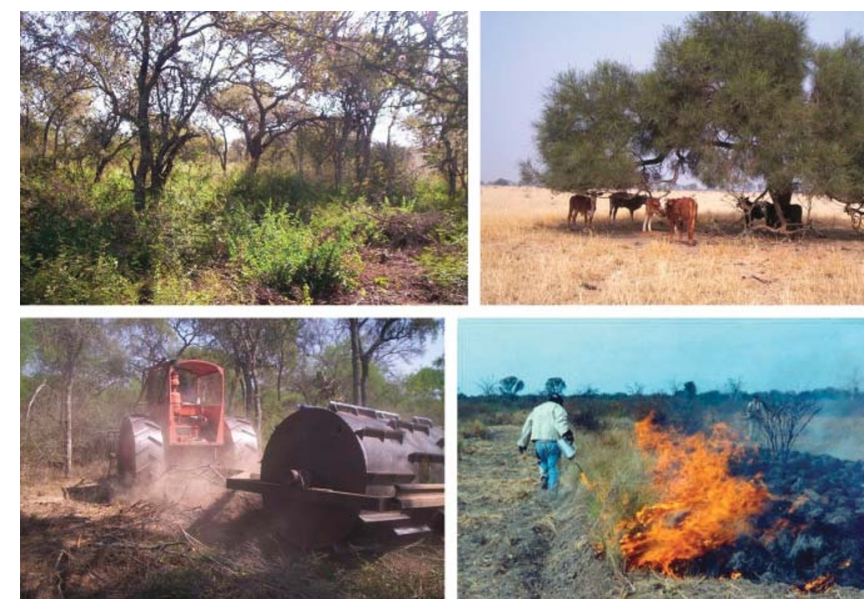

Figure 2. Chaco rangelands. Shrub invaded fachinal (upper left), open savanna (upper right), roller chopper treatment (bottom left), prescribed burn (bottom right). (Photo credits: Carlos Kunst)

\section{Current Research and Management of Argentina's Chaco, Pampa, Caldenal, and Patagonia Rangelands}

The enormous variety of rangeland environments of Argentina naturally calls for diverse and often unique research and management approaches. This section covers current research and management endeavors in four contrasting rangeland environments that occur along a $5,000-\mathrm{km} \mathrm{N}-\mathrm{S}$ latitudinal gradient. We begin our journey in the Chaco iii rangelands of the north, continue through the world-famous Pampas of central-eastern Argentina, and cross the semiarid Caldenal woodlands that provide a transition into the windswept rangelands of Patagonia, which reach deep into the southernmost tip of the South American continent. ${ }^{\text {iv }}$

\section{Woodlands, Savannas, and Grasslands of Argentina's Chaco Region}

The Chaco (Fig. 2) comprises a mosaic of forests, woodlands, grasslands, savannas, and shrublands. Forests typically occupy upland sites, whereas woodlands and savannas are located on intermediate and lowland sites, respectively. Historical records suggest that until the early twentieth century grasslands and forests shared the Chaco landscape in almost even proportions. Fire was probably responsible for that balance, since it was extensively used by the Native Americans for hunting and war. ${ }^{8}$ Today, large areas of the Chaco are covered with dense shrub thickets and secondary forests, a phenomenon that seriously restricts livestock and timber operations.

\footnotetext{
iii A Native American (quichua) word meaning "a place for hunting" and "a place where I am self-sufficient."

iv Despite its ecological importance and geographic expanse, a discussion of the Monte Region (Table 1; Fig. 1) is not included in this section. An in-depth review of research addressing the ecology and management of the Monte can be found in a recent special issue of the Journal of Arid Environments (2009, vol. 73, issue 2).
} 
The region exhibits hot summers $\left(38^{\circ} \mathrm{C}\right)$ and cold winters $\left(-10^{\circ} \mathrm{C}\right)$ with marked summer precipitation seasonality. Annual rainfall is variable and tends to decrease from 700-800 $\mathrm{mm}$ in the NW to $200-300 \mathrm{~mm}$ toward the south. ${ }^{9}$ The entire region is a vast plain, with a slight slope toward the southeast and crossed by several major rivers, such as the Bermejo, Salado, and Dulce. Sediments carried by these rivers and streams from the mountains and sierras on the west form the parent material of soils, which despite being undeveloped ( $\mathrm{A}-\mathrm{A} / \mathrm{C}$ horizons) usually have no severe limitations for root growth. Some areas toward the south, however, exhibit clayey textures and severe salt accumulations that seriously restrict plant growth, particularly in the lowland sites.

Livestock raising (cattle, mules, goats, and horses) has been the most important historic use of the land south of the Salado River since European settlement, which occurred with the Spanish conquest (ca. 1500). Intensive settlement of the Chaco north of the Salado River, on the other hand, did not begin until the early twentieth century, and native forest timber operations became the most important trade, providing fence posts, firewood, charcoal, and railway ties. Timber operations declined around 1960, and large areas of land were cleared for crops, mostly sorghum and soybean, in the "best" areas. Today cattle ranches alternate with crop farms and areas with small-scale landowners.

One of the key challenges facing range managers in the Chaco region is to match stocking rates with highly variable forage production. ${ }^{10}$ The basic tool used to improve forage availability of a paddock in poor condition is summer resting for one (annual rotational grazing) or several seasons and subsequent moderate stocking. Summer rest and stocking rate adjustments complemented with "good" rains can increase forage yields up to $300 \%$ in ranges in poor and fair condition, even in places with severe soil restrictions if shrub and tree encroachment is not severe. ${ }^{10}$ The introduction of electric fencing using solar panels has greatly improved the success of such grazing systems, whereas the sowing of gatton panic (Panicum maximum cv. Gatton panic) and buffel grass (Cenchrus ciliaris cv. Texas 4464 and Biloela) has significantly increased the general productivity of ranches as a whole. ${ }^{11}$

Rangeland improvement efforts are currently focused on restoring the following: 1) shrub thickets and secondary forests known locally as fachinales or renovales that once established are quite resilient and stable and 2) peladales (large areas with bare soils) caused by overgrazing that become important in the drier Chaco toward the south. Empirical and experimental observations indicate that these rangelands cannot be restored by applying "passive" management tools such as removing the degrading agent(s), usually livestock, or by applying a grazing system. The control of native shrub and tree populations above certain thresholds and the seeding of grass species are essential to achieve profitable forage yields and stocking rates. ${ }^{10,12}$
Although chemical treatments are not widespread in the region, herbicides have been used to control secondary forests of Prosopis nigra promoting two- to threefold increases in standing forage biomass $(2,600-4,500 \mathrm{~kg}$ dry matter/ha) compared with untreated controls $(1,400 \mathrm{~kg}$ dry matter/ha). The main setbacks to such treatments are their high cost and the environmental side effects, such as elimination of tall trees that provide both shade and forage.

Mechanical clearing is popular among Chaco ranchers because most producers have ample know-how and expertise in developing, adapting, and using agricultural machinery, a phenomenon rooted in the longstanding agronomic tradition of Argentina. Nonetheless, the conventional approach of bulldozing all standing vegetation and replacing it with annual grasses such as Sorghum, which was widespread from the late 1950s up until the early 1980s, is being gradually replaced by selective clearing practices using roller choppers (Fig. 2). Areas treated with this machinery exhibit a $200-300 \%$ increase of native forage species and forage yields of 8,000-10,000 kg dry matter/ha/year in cases where gatton panic or buffel grass are seeded. ${ }^{13}$ Roller chopper thinning usually requires some kind of follow-up treatment and must be complemented with appropriate stocking rates, prescribed fire, wood residue recycling, and/or chemical treatments to achieve the full ecosystem potential.

Prescribed fires during winter and early spring (late June to early November) are used to control shrubs (e.g., Acacia aroma, Celtis pallida, and Schinus species) and promote grass growth or reduce roller-chopping residues (Fig. 2). When areas are burned at two- to four-year intervals, no significant decrease in Total Organic Carbon and Total Organic Nitrogen in the upper soil horizon is observed. ${ }^{14}$ Reintroducing fire into Chaco's ecosystems in their current state is challenging because it requires dealing with large fuel loads of medium and coarse wood residues of high caloric power left behind by mechanical treatments, in some cases up to 30-40 tons/ha. ${ }^{13}$

Experimental observations suggest that goats may be an option to control shrub populations because they readily feed on Celtis, Acacia, and other shrub species. However, targeted grazing has not been used in the Chaco to date.

The future of range management in the Chaco region will involve the development of production systems that take advantage of both grasses and woody plants (shrubs and trees). These systems are clearly more appropriate for the Chaco ecosystems from the ecological and agronomical points of view than the "grass only" management paradigm. In fact, the Chaco shrubs and tree species are hardwoods that produce high-quality material for fencing, firewood with high caloric power, wood for furniture, shade, and forage; their foliage is also an important source of soil organic matter. The challenge for the future is to adapt the traditional methods of range management (grazing, fire, mechanical) to generate grazing paddocks that will support productive livestock herds and healthy tree populations. In addition, it will be important to develop skills to evaluate 
and adjust stocking rates that will be both profitable and sustainable.

\section{Temperate Grasslands of Argentina's Flooding Pampa}

The flooding pampas cover approximately nine million hectares of extremely flat terrain east of the Tandilia hills in the Argentine province of Buenos Aires. ${ }^{15}$ The lack of a developed natural drainage network (due mostly to the lack of topographic slope of the region) is responsible for brief flooding events that occur in most years during fallspring in the lowland areas (Fig. 3). ${ }^{16}$ The region exhibits mean monthly temperatures ranging from $6.8^{\circ} \mathrm{C}$ in the winter to $21.8^{\circ} \mathrm{C}$ in the summer and average annual rainfall of approximately $900 \mathrm{~mm}$, with no strong seasonality pattern.

Grasslands of the flooding pampas are subjected to the combined effects of grazing, floods, and droughts. Grazing reduces cover of the most palatable grasses and favors colonization of exotic and native forbs, which become codominant along with several sod grasses. ${ }^{16}$ This effect can be reverted either by animal exclusion or by floods that eliminate exotic forbs that, unlike the native species, are not adapted to water-logged conditions. ${ }^{17}$ Floods tend to improve quality and accessibility of forage.

Historically, cow-calf ranching operations accounted for most of the agricultural industry of the region. Over the last decades, a large number of ranches have increased their secondary productivity by adding grass-fed yearling finishing programs to their production system. The introduction of seeded pastures based on tall wheatgrass (Thinopyrum ponticum), tall fescue (Festuca arundinacea), and bird's foot trefoil (Lotus tenuis) $)^{18}$ together with nitrogen $(\mathrm{N})$ and phosphorous $(\mathrm{P})$ fertilization of both seeded pastures and native rangelands have enabled these system changes. Annually,
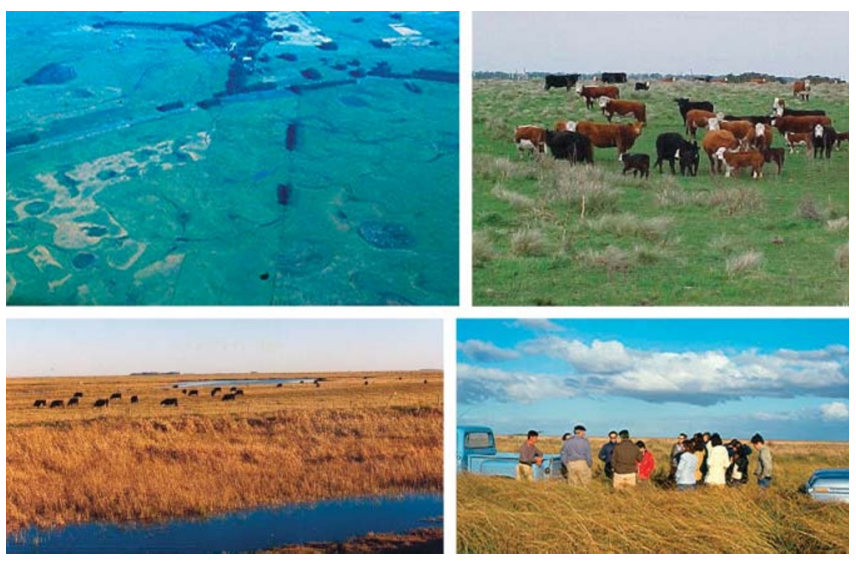

Figure 3. Aerial view of flooding Pampa rangelands located between Balcarce and Coronel Vidal showing plant community heterogeneity associated with topography in a wet year (upper left), late spring cow-calf grazing of rangelands dominated by Paspalum quadrifarium tussocks (upper right), winter cow-calf grazing of flooding Pampa rangelands (bottom left), late summer field day with ranchers on a dallisgrass (Paspalum dilatatum) dominated rangeland after a period of extended floods (bottom right). (Photo credits: Miguel A. Brizuela)
2.4 million calves, mainly of British breeds (e.g., Aberdeen Angus and Hereford), are raised in Argentina's flooding pampas. A high percentage of these calves are sent to ranches for pasture-based finishing or to feedlots in different areas of the country, where they are later sold for slaughter once they reach a weight of approximately $440 \mathrm{~kg}$ (steers) or 320 $\mathrm{kg}$ (heifers). Currently, there are 8.8 million head of cattle on flooding pampas, which account for $16 \%$ of the country's cattle population (54 million head). ${ }^{19}$

Although a considerable amount of work dealing with the structure and function of grasslands of the flooding pampas was published over the last four decades (see Further Readings online at http://dx.doi.org/10.2111/RANGELANDSD-10-00016.s1 for published works on the flooding pampas), strategies of grassland utilization were developed only fairly recently. These strategies involve dividing paddocks into grazing units, which segregate the different plant communities (high vs. low-lying areas) and grazing each community at times of the year when they provide the best nutrition for cattle. $^{20}$

Flooding pampas grasslands can sustain year-round growth; however, forage production during the springsummer period is approximately eight to 10 times higher than in winter, a phenomenon that undoubtedly affects livestock production. If soil moisture and $\mathrm{P}$ levels are adequate $(20 \mathrm{~kg} \mathrm{P} / \mathrm{ha})$, winter $\mathrm{N}$ fertilization can increase both late winter forage production (i.e., spring regrowth begins 25 to 30 days earlier) and overall annual production, with forage accumulations of 8-10 tons DM/ha/year, four to five times higher than those obtained without fertilization. ${ }^{20}$ In addition, $\mathrm{N}$ fertilization promotes an increase in the production of high-quality forage (up to $2.5-3.0 \% \mathrm{~N}$ and $75 \%$ dry matter digestibility), which enables ranchers to establish grass-fed yearling finishing programs. ${ }^{21}$ Currently, plant community-specific fertilization is used by approximately $20 \%$ of ranchers ${ }^{22}$ as a tool to increase forage production and modify the pattern of annual forage distribution by extending the growth season of $\mathrm{C}_{3}$ grasses.

The use of glyphosate as a means of promoting winter pasture productivity has been widely adopted in recent years. Natural vegetation is replaced by annual ryegrass, a strategy that has unfortunately led to a reduction in the abundance of the native cool and warm season grasses of high nutritive value and has favored perennial weed and annual grasses of low forage value. Consequently, grasslands treated repeatedly with herbicides currently exhibit a forage production peak during the winter-spring period at the expense of a decrease in summer grass production. To counter this, prescribed grazing is being successfully used as an alternative to herbicides. This strategy consists of intense grazing during Argentina's summer (January-February) to avoid the accumulation of growth and thus facilitate the emergence and establishment of annual ryegrass without affecting warm season species abundance.

Traditional year-round continuous grazing has led to a reduction in cool season grasses, an increase in weeds and 
bare soil, and overall grassland degradation, which have resulted in decreased carrying capacity, poorer animal performance, and lower profitability. More recently, many of the better soils have been plowed to grow crops, a phenomenon that has posed the challenge of maintaining the same number of livestock in a smaller area. This has given way to new management strategies that propose seasonal adjustments of the instantaneous stocking density. ${ }^{20,21} \mathrm{~A}$ number of studies have shown that rotational grazing can double cool season grass production (including annual ryegrass which can account for as much as $77 \%$ of cool season biomass increase) and promote an increase in forage quality and a decrease in undesirable plants and bare soil. This increase in winter forage productivity allowed rotational systems to be stocked at almost twice the rate of traditional continuous systems (1.0 vs. 0.6 AU/ha). Proposed rotational grazing systems can improve grassland condition and enhance the nutrition of grazing animals. Less intensive systems involving continuous grazing with variable stocking rates in fertilized pastures have also shown promising results. ${ }^{21}$

The reduction of rangeland area available for traditional cow-calf operations and the displacement of animal agriculture to less productive rangelands have been singled out as a critical bottleneck in Argentina's beef production chain today. The application of substantially higher fertilization rates and improved nutritional and reproductive management of the herd have been suggested as the only way to maintain historical mother cow herd numbers. More research is needed to develop management guidelines to meet the challenges of this new land management scenario.

\section{The Caldenal Region of Central Argentina}

The caldenal is a southern continuation of the "espinal" ecoregion (Fig. 1) and comprises an ecotone between the Pampa grasslands and the Monte desert to the west, growing along a precipitation gradient that ranges between 600 and $400 \mathrm{~mm} /$ year. This ecosystem is dominated by Prosopis caldenia, an endemic deciduous tree that forms monospecific stands with a well-developed grass layer which includes short perennial thin grasses (e.g., Piptochaetium napostaense, Stipa tenuis, Poa ligularis, Aristida subulata, Trichloris crinite, and Digitaria califórnica). Low palatability perennial bunchgrasses include Stipa tenuissima, Stipa ichu, Stipa brachychaeta, and Stipa ambigua (Fig. 4).

The Caldenal occurs in valleys with loamy, well-developed soils and with a thin petrocalcic layer at variable depths from few centimeters to more than $1.5 \mathrm{~m}$. Tallest trees are found in well-developed soils in the northern and central part of the region, while in less developed soils with lower precipitation, other woody species become important (e.g., Prosopis flexuosa, Condalia microphylla, Geoffroea decorticans,

${ }^{\vee}$ According to a recent unpublished report produced by Daniel Rearte INTA Balcarce.
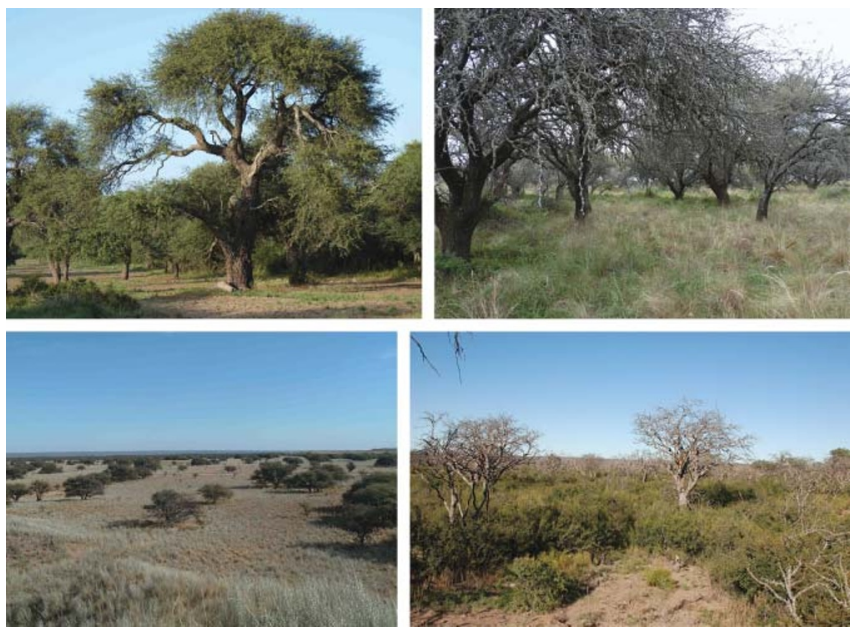

Figure 4. Rangelands of the Caldenal region of central Argentina. Open $P$. caldenia woodland with understory dominated by palatable fine grasses (upper left) or unpalatable bunchgrasses (upper right). Calden invasion of a degraded dune grassland (lower left) and fire-maintained shrub thicket structure (lower right). (Photo credits: H. Raúl Peinetti)

Schinus fasciculatus, and Jodina rhombifolia). P. caldenia can reach more than $12 \mathrm{~m}$ height with approximately $1.5 \mathrm{~m}$ of main stem diameter. The oldest dated trees were more than 250 years old. This tree produces an indehiscent pod that is considered a valuable forage resource for livestock.

The characteristics of the Caldenal depend in large part on factors that control the balance between woody and grass vegetation, as occurs in other arid and semiarid regions of the world. Human disturbances including livestock grazing, logging, and changes in fire frequency and intensity have largely altered this balance. Livestock was introduced in this area as early as the 1700 s by nomadic herding Indians who moved livestock from the Argentinean pampas to southern Chile. The impact of this herding activity is evident today. Major ecological changes occurred in the early 1900s when livestock began to be raised in fenced paddocks at high stocking rates. Sheep grazing was prevalent during the first half of 1900s and were then replaced by cattle that have grazed this area until today. Two severe periods of logging devastated the Caldenal in the 1910s and 1940s. The original cover range of the Caldenal woodlands has been largely fragmented by clearing areas to grow crops or to establish cultivated pastures. Fire intensity and frequency have also been altered by human activities since European settlement of this area.

Livestock dispersal of $P$. caldenia seeds as well as favorable conditions for establishment of other woody species (C. microphylla, S. fasiculatus) has led to an increase in woody plant density in the savanna and the spread of woody species to contiguous semiarid grasslands ${ }^{23}$ (Fig. 4). The increase in woody plant density alters the structure of the caldenal from a savanna parkland to a dense woodland/forest with a well-developed shrub layer. This highly dense woody plant formation dramatically increases the intensity of fires that kill aboveground woody biomass, stimulating resprouting of 
woody plants and generating shrubby thickets with few medium-size trees $(6-10 \mathrm{~m})$ and very low grass cover. Positive feedback loops between woody plant density and fires have severely reduced desired open savanna vegetation structure in this area nowadays.

A major problem in areas of the Caldenal where woodland structure is considered to be in better condition is the replacement of palatable grass species (fine grasses) in the herbaceous understory by bunchgrasses of low palatability due to continuous grazing, ${ }^{24}$ so much so that some of the palatable grass species have disappeared from the seed bank. The reconstruction of the floristic history of the area using soil phytolithic studies, which go back approximately 100 years, indicates the prevalence of desirable grass species prior to livestock introduction. Current areas of Caldenal dominated by unpalatable bunchgrasses most probably are the result of high livestock grazing pressure. Prescribed burning appears to improve range forage condition but cannot be used to reduce shrub encroachment. Current management in the Caldenal focuses almost exclusively on improving forage availability for livestock; however, there is a need for an integrated management approach to restore a degraded ecosystem..$^{25,26}$

\section{Cold Deserts and Semi-Deserts of Argentina's Patagonia}

Patagonia includes almost half of Argentina's arid and semiarid shrublands and grasslands $\left(780,000 \mathrm{~km}^{2}\right)$, which exhibit a relatively high rate of endemism and biodiversity. Most of the region is classified as a cold semi-desert with mean annual temperatures that rarely exceed $10^{\circ} \mathrm{C}$ and rainfall levels ranging from 150 to $250 \mathrm{~mm} /$ year. Patagonia's landscapes span more than $13^{\circ}$ in latitude and exhibit altitudes

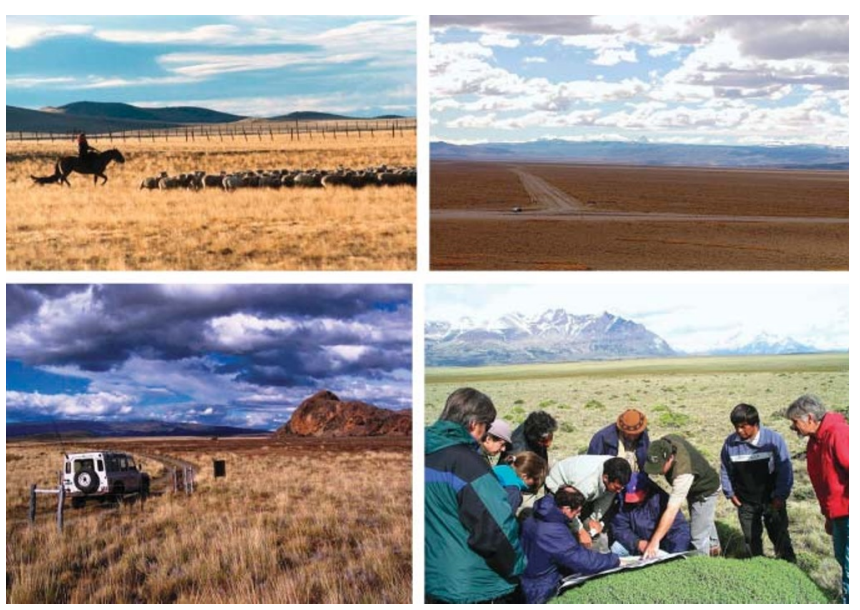

Figure 5. Rangelands of Patagonia. Sheep herding on the fescue grass steppes of southern Patagonia at INTA's Potrok Aike Experimental Range (upper left), dwarf shrub steppes of the plateaus of southcentral Patagonia (upper right), mesic fescue grass steppes surrounding the Straits of Magellan (bottom left), a group of rangeland specialists conducting rangeland survey training on rangelands of the Andes foothills (bottom right). (Photo Credits: Gabriel Oliva) that range from sea level to over $3,800 \mathrm{~m}$. The region includes twelve bio-zones, seven of which are arid-scrub or grasslands ${ }^{27}$ (Fig. 5).

Sheep were introduced in the region in the late 1800s and reached 20 million by 1950 . There are currently 13,000 livestock producers in the region, $80 \%$ of which are smallholders that operate subsistence enterprises, $17 \%$ run midscale operations, and 3\% manage large ranches. Most of the land is grazed continuously, with some seasonal use of higher altitude rangelands and a few mobile pastoralists. Low-input sheep ranching is practiced across the region, with little use of supplementation or winter feeding. Land was overstocked by European settlers, and overgrazing at a regional scale was the rule for over half a century. In recent decades, rangeland degradation, low wool prices, and higher production costs induced a reduction in flocks to 8.4 million sheep.

Approximately 400 midsized ranches of central Patagonia comprising 10 million ha have been abandoned. Approximately $85 \%$ of the area is affected by different degrees of desertification. In fact, land degradation is one of the most urgent ecological issues in the region. Biological invasions are not important in most of the region, although exotic herbivores (rabbits and beavers) and forb species such as the mouse ear hawkweed (Hieracium pilosella) pose significant management challenges in subhumid rangelands of southern Patagonia. Oil and gas production have a widespread impact over vast areas, and mining is responsible for more concentrated impacts affecting both vegetation and soil and water quality.

Although overgrazing-related degradation is thought to have caused a reduction in plant diversity ( 75 plant species were listed as endangered $)^{28}$ and sheep grazing has been linked to a reduction or local disappearance of preferred grasses, ${ }^{29}$ long-term stocking rate studies have shown that moderate sheep grazing can maintain or even slightly increase plant species richness. ${ }^{29,30}$ Other authors have found that some degree of rest or grazing deferment is necessary to allow for rangeland regeneration. ${ }^{31}$

Changes in Patagonian plant communities triggered by overgrazing have been described in terms of state-andtransition theory ${ }^{32}$ and generally involve the replacement of grasses by shrubs, the loss of fine topsoil particles (silts) along with organic matter and nutrients, ${ }^{33}$ and the increase of bare soil. Degraded rangelands also lose structural attributes that connect a network of source and sink patches. Nutrients, soil, and plant propagules that are displaced by aeolic erosion are lost from the system.

Over the last 20 years, techniques have been developed to promote sustainable range management. A set of such techniques widely applied in southern Patagonia is known as the Low Input Management Technology packet (Tecnología de Manejo Extensivo [TME]). Briefly, TME proposes a rangeland inventory using remotely sensed images followed by a field assessment of forage availability. ${ }^{34}$ Information on animal production indices is obtained and 
production and marketing goals are clearly established with the rancher. A grazing plan is then designed ensuring that nutritional needs of the flock are met while leaving adequate forage residue (approximately half the above ground biomass of preferred forages). The "take half leave half" rule of thumb ensures regeneration of most plant species including palatable grasses. When possible, recovery is further promoted using rest and deferred rotation, especially in paddocks that include meadows (mallines). In northern Patagonia, where smallholders predominate, sustainable production also involves strategic investment in infrastructure (fencing, shelters for livestock, water supply, etc.). The goal is to increase smallholders' income through improved meat and wool production. ${ }^{35}$

Grazing plans are combined with a series of improved animal husbandry practices, including the adjustment of flock age structure, pre-lambing shearing, Tally Hi or Bowen shearing, wool conditioning and classification, as well as the use of noncontaminating packaging for wool bales. Rams are examined to avoid reproductive diseases, and breeding dates are adjusted to ensure optimal lambing and weaning seasons. A genetic improvement and flock health management plan is established, and selective predator control methods are recommended. In some cases forage reserves are also recommended, especially in areas with a high risk of severe winter snow storms.

In southern Patagonia only $6 \%$ of sheep ranchers ( 2 million ha) have adopted the TME packet. This low adoption rate is explained by the strong traditional component of sheep production and poor financial results that may have prevented ranchers from seeking technical advice. Although sheep ranching as a whole has lost importance in the regional economy relative to other activities, it still constitutes part of the traditions and cultural heritage of the region and contributes to sustainable occupation of the land. In fact, the future of livestock grazing on Patagonian rangelands can be viewed with moderate optimism. A combination of better international commodity prices, a tendency shifting toward markets that prioritize environment-friendly agricultural products and new management tools based on appropriate technology may jointly help to avoid land degradation and attain sustainable production.

\section{The 2011 International Rangeland Congress}

Argentina will be the first South American country to host an International Rangeland Congress. The theme of the 2011IRC will be Diverse Rangelands for a Sustainable Society and will cover aspects of agricultural, ecological, and social sustainability of rangeland ecosystems. Pre-congress tours to several regions including those outlined in this paper will offer a unique opportunity for firsthand experience and in-depth discussion about local rangeland management issues with researchers and managers from both the local and international rangeland community (www.irc2011.com. ar). This paper seeks to contribute to providing perspective and background for colleagues and friends who are planning to attend what promises to be a truly memorable rangeland congress.

\section{Acknowledgments}

This paper summarizes a series of papers that were presented at a Symposium on Rangelands of Argentina at the 60th Annual Meeting of the Society for Range Management in 2007. This symposium was organized by the International Affairs Committee of the Society for Range Management and was sponsored by Dow Agro Sciences, Society for Range Management, Instituto Nacional de Tecnología Agropecuaria (Argentina), and NSF-LTER Jornada Experimental Range. Two anonymous reviewers provided comments that helped improve our manuscript. We are particularly indebted to one of our reviewers for offering detailed suggestions that greatly improved the section of our paper that describes Argentine rangeland types.

\section{References ${ }^{\text {vi }}$}

1. Morrison, J. J. 1917. La ganadería en la región de las mesetas australes del territorio de Santa Cruz [thesis]. Buenos Aires, Argentina: Facultad de Agronomía y Veterinaria Buenos Aires. $172 \mathrm{p}$.

2. Hauman, L. 1920. Ganadería y geobotánica en la Republica Argentina. Buenos Aires, Argentina: Centro de Estudiantes de Agronomía y Veterinaria. Revista del Centro de Estudiantes de Agronomía y Veterinaria 102. 21 p.

3. Davies, W. 1940. The grasslands of the Argentine and Patagonia. Aberystwyth, Wales: Herbage Pub. Ser. Bulletin 30. $46 \mathrm{p}$.

4. Boelcke, O. 1957. Comunidades herbáceas del norte de la Patagonia y sus relaciones con la ganadería. Revista de Investigaciones Agricolas 11:5-98.

5. Soriano, A. 1956. Aspectos ecológicos y pastoriles de la vegetación patagónica relacionados con su estado y capacidad de recupero. Revista de Investigaciones Agricolas 10:349-372.

6. CONEAU. 2003. Acreditación de carreras de grado de Ingeniería Agronómica en el marco del MEXA. Taller de Pares Evaluadores. Ciudad de Buenos Aires. Available at: www.coneau. gov.ar. Accessed 14 January 2011.

7. CONEAU. 2003. La acreditación de las carreras de Agronomía en Estados Unidos, en Argentina y en los procesos de integración regional. Seminario Taller ABET/CONEAU. Ciudad de Buenos Aires. Available at: www.coneau.gov.ar. Accessed 14 January 2011.

8. Bravo, S., C. Kunst, A. Giménez, and G. Moglia. 2001. Fire regime of a Elionorus muticus Spreng. savanna, western Chaco region, Argentina. International Journal of Wildland Fire 10:1-8.

9. Boletta, P. 1988. Clima. In: R. Casas [ed.]. Desmonte y habilitación de tierras en la región chaqueña semiárida. Santiago, Chile: FAO. p. 7-21.

10. Blanco, L., C. Ferrando, E. Orionte, F. Biurrun, G. Berone, D. Recalde, and P. Namur. 2005. Relación entre la

\footnotetext{
vi See Further Readings online at $h$ ttp://dx.doi.org/10.2111/RANGELANDSD-10-00016.s1 for additional literature on Argentina's rangeland ecology, management, and education.
} 
producción forrajera y las precipitaciones en comunidades autóctonas de los Llanos de La Rioja. Revista Argentina de Producción Animal 25:200-201.

11. Ferrando, C., P. Namur, L. Blanco, G. Berone, and T. VERA. 2005. Módulo experimental de cría, buffelgrass-pastizal natural en Los Llanos de La Rioja: índices productivos. Revista Argentina de Producción Animal 25:316-317.

12. Fumagalli, A., C. Kunst, and H. Pérez. 1997. Intensificación de la producción de carne en el NOA. In: J. Carrozzino and D. Rearte [eDs.]. Memoria del 1er. Congreso Nacional de Producción Intensiva de Carne. Buenos Aires, Argentina: INTA-Foro Argentino de Forrajes. p. 53-61.

13. Kunst, C., J. Casillo, R. Ledesma, and J. Godoy. 2006. Rolados y residuos leñosos: I. Estimación de la carga de combustibles. In: Actas Ecofuego-II reunión Patagónica y III Reunión Nacional sobre Ecología y Manejo de Fuego. Esquel, Chubut, Argentina: CIEFAP. p. 197-203.

14. Gonzalez, C., G. Studdert, C. Kunst, and A. Albanesi. 2001. Comportamiento de algunas propiedades del suelo en una sabana del Chaco semiárido occidental bajo distintas frecuencia de fuego. Ciencia del Suelo (Argentina) 19:92-100.

15. Etchevehere, P. 1961. Bosquejo de regiones geomorfológicas y del drenaje de la República Argentina. Revista IDIA 162:7-25.

16. Chanetón, E. J., S. B. Perelman, M. Omancini, and R. J. C. LEón. 2002. Grazing, environmental heterogeneity, and alien plant invasions in temperate Pampa grasslands. Biological Invasions 4:7-24.

17. Chanetón, E. J., J. M. Facelli, and R. J. C. León. 1988. Floristic changes induced by flooding on grazed and ungrazed lowland grasslands in Argentina. Journal of Range Management 41:182-187.

18. Vignolio, O. R., and O. N. Fernandez. 2006. Bioecología de Lotus glaber Mill. (Fabaceae) en la Pampa Deprimida (provincia de Buenos Aires, Argentina) Revista Argentina de Producción Animal 26:113-130.

19. Rearte, D. 2006. Argentinean meat production. Meat Production Program, INTA. Balcarce, Argentina: INTA. Documento del programa nacional de Producción de Carnes. 25 p.

20. Fernández Grecco, R. C., A. Mazzanti, and H. E. Echeverría. 1995. Efecto de la fertilización nitrogenada sobre el crecimiento de forraje de un pastizal natural de la Pampa Deprimida bonaerense (Argentina). Revista Argentina de Producción Animal 15:173-176.

21. Rodríguez Palma, R., A. Mazzanti, M. G. Agnusdei, and R. C. Fernández Grecco. 1999. Fertilización nitrogenada y productividad animal en pastizales bajo pastoreo continuo. Revista Argentina de Producción Animal 19:301-310.

22. Cástino, E. G. 2006. Pasturas: estimación y modalidad de uso de fertilizantes. Available at: http://www.fertilizar.org.ar/ vertext.php?id_nota=238. Accessed 9 September 2010.

23. Dussart, E., P. Lerner, and H. R. Peinetti. 1998. Long term dynamics of 2 populations of Prosopis caldenia Burkart. Journal of Range Management 51:685-691.

24. Llorens, E. M. 1995. The sate and transition model applied to the herbaceous layer of Argentina's calden forest. Journal of Range Management 48:442-447.

25. Busso, C. A. 1997. Towards an increased and sustainable production in semi-arid rangelands of central Argentina: two decades of research. Journal of Arid Environments 36:197-210.

26. Fernández, O. A., M. E. Gil, and R. A. Distel. 2009. The challenge of rangeland degradation in a temperate semiarid region of Argentina: the Caldenal. Land Degradation and Development 20:431-440.

27. Paruelo, J. M., E. G. Јobbagy, and O. E. Sala. 1998. Biozones of Patagonia. Ecología Austral 8:145-153.

28. Soriano, A., M. Nogués Loza, and S. Burkart. 1995. Biodiversity in the extra-Andean Patagonia: comparison with neighboring and related vegetation units. In: L. Montes and G. Oliva [EDs.]. Actas del Taller Internacional sobre recursos fitogenéticos desertificación y uso sustentable. Buenos Aires, Argentina: Centro Regional Patagonia Sur INTA. p. 36-45.

29. Oliva, G., A. Cibils, P. Borrelli, and G. Humano. 1998. Stable states in relation to grazing in Patagonia: a 10-year experimental trial. Journal of Arid Environments 40:113-131.

30. Oliva, G., M. Collantes, and G. Humano. 2005. Demography of grazed tussock populations in Patagonia. Rangeland Ecology \& Management 58:466-473.

31. Golluscio, R., C. Giraudo, P. Borrelli, L. Montes, G. Siffredi, G. Cechi, V. Nakamatsu, and J. Escobar. 1998. Utilización de los recursos naturales en la Patagonia. In: DHV Consultants (Holland) and SCC Swedforest International AB (Sweden) [EDs.]. Ecosistemas desérticos Patagónicos. Buenos Aires, Argentina: Secretaría de Agricultura, Ganadería, Pesca y Alimentación. República Argentina. p. 1-82.

32. Paruelo, J. M., M. B. Bertiller, T. M. Schlichter, And F. R. Coronato. 1993. Secuencias de deterioro en distintos ambientes patagónicos: su caracterización mediante el modelo de estados y transiciones. Bariloche, Argentina: Convenio INTA-GTZ. Proyecto LUDEPA. p. 5-13.

33. Oliva, G., C. Bartolomei, and G. Humano. 2000. Recuperación de vegetación y suelos por exclusión del pastoreo en la Estepa Magallánica. In: XI Conferencia International Soil Conservation Association (ISCO 2000). Buenos Aires, Argentina. p. 22-27.

34. Borrelli, P., and G. Oliva. 2001. Evaluación de pastizales. In: P. Borrelli and G. Oliva [EDs.]. Ganadería ovina sustentable en la Patagonia Austral: tecnología de manejo extensivo. Buenos Aires, Argentina: INTA. p. 163-168.

35. Villagra, S. 2002. Fencing and sheltering increases the number of marketable lambs in northern Patagonia, Argentina [thesis]. Georg-August University, Göttingen, Germany. 122 p.

Authors are Land Manager with the US Dept of Defense, White Sands Missile Range, Las Cruces, NM 88002 USA (Anderson); Range Scientist, Instituto Nacional de Tecnología Agropecuaria, Argentina (Bonvissuto); Professor, Facultad de Ciencias Agrarias, Universidad Nacional de Mar del Plata, Argentina, and Comisión de Investigaciones Científicas de la Provincia de Buenos Aires, Argentina (Brizuela); Extension Specialist, Instituto Nacional de Tecnología Agropecuaria, Argentina (Chiossone); Associate Professor of Rangeland Science, Dept of Animal and Range Sciences, New Mexico State University, Las Cruces, NM 88003, USA (Cibils), acibils@mnsu.edu; Professor, Facultad de Ciencias Agrarias, Universidad Nacional de Mar del Plata, Argentina, and Comisión Nacional de Investigaciones Científicas y Técnicas, Argentina (Cid); Private Consultant and Rancher, Rosario, Argentina (Feldman); Animal Scientist, Instituto Nacional de Tecnología Agropecuaria, Argentina (Fernández Grecco); Range Scientist, Instituto 
Nacional de Tecnología Agropecuaria, Argentina (Kunst); Professor, Facultad de Agronomía, Universidad de Buenos Aires, Argentina, and Comisión Nacional de Investigaciones Científicas y Técnicas, Argentina (Oesterheld); Range Scientist, Instituto Nacional de Tecnología Agropecuaria, Argentina (Oliva); Professor, Facultad de Agronomía,
Universidad de Buenos Aires, Argentina, and Comisión Nacional de Investigaciones Científicas y Técnicas, Argentina (Paruelo); Associate Professor, Facultad de Agronomía, Universidad Nacional de La Pampa, Argentina (Peinetti); and Range Scientist, Instituto Nacional de Tecnología Agropecuaria, Argentina (Villagra).

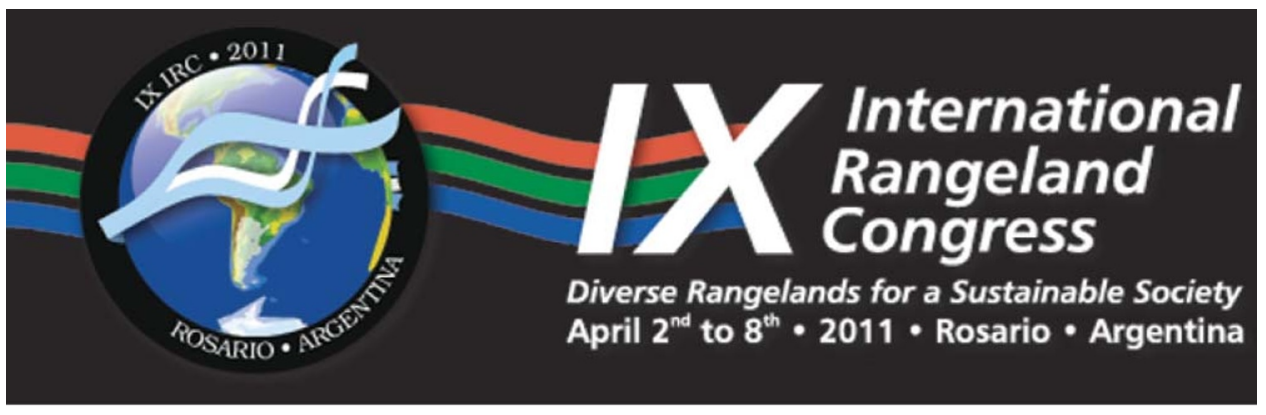

http://www.irc2011.com.ar/en/ 